\title{
Multiresidue Methods for Determination of Pesticides using SPME and SPE Followed by GC-NPD System: a Comparative Study
}

\author{
Maria A. L. Milhome, ${ }^{a}$ Paula L. R. Sousa, ${ }^{b}$ Denis De Keukeleire ${ }^{c}$ and \\ Ronaldo F. Nascimento ${ }^{*} d$ \\ ${ }^{a}$ Departamento de Engenharia Hidráulica e Ambiental, Bloco 713, Centro de Tecnologia and \\ ${ }^{d}$ Departamento de Química Analítica e Físico-Química, bloco 940, Centro de Ciências, \\ Universidade Federal do Ceará, Campus do Pici, 60451-970 Fortaleza-CE, Brazil \\ ${ }^{b}$ Fundação Núcleo de Tecnologia Industrial do Ceará (NUTEC), Rua Rômulo Proença s/n, Pici, \\ 60455-700 Fortaleza-CE, Brazil
}

${ }^{c}$ Ghent University, Faculty of Pharmaceutical Sciences, 9000 Ghent, Belgium

\begin{abstract}
Neste estudo, métodos multirresíduos usando extração em fase sólida (SPE) e microextração em fase sólida (SPME) são comparados na determinação de pesticidas em amostras aquosas. Parâmetros como tipo de fibras e espessura, solvente de eluição, volume da amostra, tempo de equilíbrio, coeficiente de partição e solubilidade foram investigados. Resultados satisfatórios foram obtidos para a análise de pesticidas usando cartuchos C18 e acetato de etila como eluente, com taxas de recuperação entre 75-107\%. As melhores condições para SPME foram com uma fibra PDMS $100 \mu \mathrm{m}$ de espessura, volume de amostra de $40 \mathrm{~mL}$, e tempo de equilíbrio de $45 \mathrm{~min}$. O método SPME é o mais adequado para a análise de pesticidas em água, devido à sua rapidez e simplicidade e ao não uso de solventes. Os limites de detecção e quantificação são inferiores aos limites de concentração máximos estabelecidos pelas autoridades brasileiras, sendo portanto aceitável.
\end{abstract}

In this study, multiresidue method using solid phase extraction (SPE) and solid phase microextraction (SPME) are compared in the determination of pesticides in aqueous samples. Parameters such as fiber type and thickness, elution solvent, sample volume, equilibration time, partition coefficient and solubility were investigated. Satisfactory results were obtained for the analysis of pesticides using C18 cartridges and ethyl acetate as eluent, whith recovery rates between $75-107 \%$. The best conditions for SPME fiber were PDMS with a $100 \mu \mathrm{m}$ thick, sample volume of $40 \mathrm{~mL}$, and reaction time was $45 \mathrm{~min}$. SPME method is most suitable for the analysis of pesticides in water, due to its speed and simplicity and solvent-free. The limits of detection and quantification are below the maximum concentration limits established by Brazilian authorities and therefore acceptable.

Keywords: pesticides, SPME, water analysis, microextraction, partition coefficient

\section{Introduction}

The protection of water quality is a real concern of government agencies that control public health. The worldwide intensive use of pesticides plays a key role in environmental contamination, especially in water resources. In the last years, Brazil has been considered the largest consumer of pesticides in the world. ${ }^{1}$ Only in 2009, around 1 million ton of pesticides were sold in the

*e-mail: ronaldo@ufc.br country,mainly applied in soybean, corn, sugarcane and cotton cultures. ${ }^{1}$ According to ANDEF, there were about 475 active ingredients and 1278 products registered. ${ }^{2}$

Pesticides that remain in the environment or reach the aquatic systems pose risks to animal species by their toxicity and ability to bio-accumulate along the food chain. ${ }^{3}$ The European Community has set the value of $0.1 \mathrm{mg} \mathrm{L}^{-1}$ for any individual pesticide and $0.5 \mathrm{mg} \mathrm{L}^{-1}$ for the total pesticide residues of pesticides. In Brazil, the maximum concentrations of pesticides in water are regulated by the Administrative Rule No. 518/2004 (drinking water) of the 
Ministry of Health, by The National Environment Council (CONAMA) Resolution No. 357/2005(classification of water resources), and, recently, by CONAMA Resolution No. 396/2008 (groundwater). ${ }^{4-6}$

The analysis of pesticides in water is commonly performed by chromatographic methods due to the high accuracies and sensitivities. ${ }^{7}$ Selective nitrogen and phosphorus (NPD) detectors are particularly suitable for the analysis of organophosphorus pesticides. However, low-limit of detection of pesticides in aqueous wastes, as required by environmental agencies, necessitates development of highly efficient and reliable extraction procedures. Various techniques have been used for the extraction of pesticide residues in aqueous matrices, such as liquid-liquid extraction and solid-phase extraction (SPE). ${ }^{8-10}$ Although efficient techniques are known, appropriate adaptation is needed in order to reduce the volume of organic solvents and the analysis time.

Solid-phase extraction is a widely used method that requires small volumes of solvent for elution. However, to achieve very low concentration detection limits in the chromatographic system, analyses in water require large sample volumes. Solid-phase microextraction is simple and fast, therefore, the technique has been applied for the determination of micro-pollutants, including non-volatile and volatile organic compounds, phenolics, polycyclic aromatic hydrocarbons, and pesticides. ${ }^{11,12}$ The application of SPME for retention of pesticides has been reported in various matrices including soil, ${ }^{8}$ food, ${ }^{13,14}$ river water, ${ }^{15}$ rain water, ${ }^{16}$ raw and treated water, ${ }^{17}$ groundwater ${ }^{18,19}$ and aqueous matrizes. ${ }^{20-26}$ The technique consists in the extraction of analytes using a silica fiber coated with a layer of sorbent, which is exposed directly in the sample or in the headspace. After the equilibrium time has been reached, the fiber is introduced into the chromatographic system for desorption of the analytes. Optimization of SPME involves mainly the selection of the type and the thickness of the fiber, the determination of the exposure time of the analyte in the fiber to reach equilibrium, the influence of the sample volume, the time and the temperature of desorption. ${ }^{27}$

Several methods have been published multiresidues using detection by mass spectrometry. ${ }^{28-31}$ However, nitrogen and phosphorus detector combined with an appropriate extraction method is also able to detect different classes of pesticides with high sensitivity. Our study aimed at comparing SPE and SPME extraction procedures for pre-concentration of selected pesticides from aqueous matrices in order to achieve the detection levels required by Brazilian legislation. The pesticides were selected based on high consumption in regional cultures as well as on control measures by environmental agencies. ${ }^{32}$

\section{Experimental}

\section{Reagents and chemicals}

The standard pesticides used in this work were molinate (Sigma, Brazil, purity 99\%), methyl parathion (Sigma, Brazil, purity 99.8\%), malathion (Sigma, Brazil, purity 99\%), chlorpyrifos (Sigma, Brazil, purity 99\%), fenitrothion (Sigma, Brazil, purity 99\%), pendimethalin (Thorium, Brazil, purity 98.8\%), triazophos (Sigma, Brazil, purity $99 \%$ ). The main physicochemical characteristics of the pesticides studied are given in Table 1.

Methanol (Vetec, Brazil ), ethyl acetate (Vetec, Brazil), hexane (Vetec, Brazil), acetone (Vetec, Brazil), and dichloromethane (Vetec, Brazil ) and Milli-Q water was used for the preparation of solutions and the extraction of samples.

\section{Standards and samples}

Stock solutions of individual pesticides were prepared by diluting $10 \mathrm{mg}$ of the analyte in $10 \mathrm{~mL}$ of ethyl acetate. Solutions of mixtures of pesticides $\left(10 \mathrm{mg} \mathrm{L}^{-1}\right)$ were prepared from solutions of individual pesticides. Calibration curve were obtained in the range $0.005-1.500 \mathrm{mg} \mathrm{L}^{-1}$ and value of the correlation coefficient $(\mathrm{R})$ of each compound.

\section{Solid-phase extraction (SPE)}

The recovery of the pesticides was achieved by solid-phase extraction (SPE) using a Manifold System (Supelco, São Paulo, Brazil), which enables extraction of up to 12 samples simultaneously. C18 and Florisil cartridges of $500 \mathrm{mg}$ per $6 \mathrm{~mL}$ were used. Different solvents (dichloromethane, ethyl acetate and hexane:acetone) were tested for elution of the analytes. The SPE cartridge was previously conditioned with $10 \mathrm{~mL}$ methanol:water $(80: 20 \mathrm{v} / \mathrm{v})$ and $10 \mathrm{~mL}$ methanol $(30 \% \mathrm{v} / \mathrm{v})$. Aqueous solutions containing the pesticides $(250 \mathrm{~mL})$ were percolated through the cartridges at a flow rate of $2 \mathrm{~mL} \mathrm{~min}^{-1}$. The analytes were eluted with $1 \mathrm{~mL}$ of an adequate solvent and then injected in duplicate in a gas chromatograph coupled to a selective nitrogen-phosphorus detector (GC-NPD). Four concentrations $\left(1.0,2.0,4.0\right.$ and $\left.8.0 \mu \mathrm{g} \mathrm{L} \mathrm{L}^{-1}\right)$ were used to investigate the recovery of the pesticides for each cartridge and eluting solvent selected. Calibration curves were allowed to obtain the value of the correlation coefficient $(\mathrm{R})$ of each compound.

\section{Solid-phase microextraction (SPME)}

Two commercially available fibers of polydimethylsiloxane (PDMS; $100 \mu \mathrm{m}$ thickness) and Carboxen-PDMS 
Table 1. Main physicochemical characteristics of the pesticides studied

\begin{tabular}{|c|c|c|c|c|c|}
\hline Pesticide & Structure & Class & Toxicity & Solubility / $\left(\mathrm{mg} \mathrm{L}^{-1}\right)$ & $\log K_{\text {ow }}$ \\
\hline Molinate & & Thiocarbamates & II & 1100 & 2.86 \\
\hline Methyl parathion & & Organophosphates & I & 55 & 3.00 \\
\hline Fenitrothion & & Organophosphates & II & 19 & 3.32 \\
\hline Malathion & & Organophosphates & III & 148 & 2.75 \\
\hline Clorpyrifos & & Organophosphates & II & 1.05 & 4.70 \\
\hline Pendimethalin & & Dinitroanilines & III & 0.33 & 5.20 \\
\hline Triazophos & & Organophosphates & II & 35 & 3.55 \\
\hline
\end{tabular}

(75 $\mu \mathrm{m}$ thickness) were evaluated for their extraction efficiencies towards the pesticides. The fibers were initially conditioned for at least $1 \mathrm{~h}$ at $250-300{ }^{\circ} \mathrm{C}$, according to the manufacturer's instructions. The conditioned fiber was immersed into the aqueous solution and maintained at the equilibrium time under stirring $(150 \mathrm{rpm})$ at ambient temperature $\left(28 \pm 2{ }^{\circ} \mathrm{C}\right)$. After extraction, the fiber was thermally desorbed during 5-10 min into the glass liner of the GC injection port. The equilibrium time was determined by varying the exposure time of the fiber in $30 \mathrm{~mL}$ of a spiked sample $\left(4 \mu \mathrm{g} \mathrm{L}^{-1}\right)$ for $15,30,45$ and $60 \mathrm{~min}$. The effects of the sample volumes on the retention of the pesticides were evaluated using volumes of 20, 40 and $80 \mathrm{~mL}$. A five-level calibration curve was constructed using aqueous standards ( 1.0 to $8.0 \mu \mathrm{g} \mathrm{L}^{-1}$ ) that were extracted in the same conditions as those applied for the samples. The values of the limits of detection and of quantification were calculated by equations 1 and 2, respectively,

$\mathrm{LOD}=3.3 \times(\mathrm{s} / \mathrm{S})$
$\mathrm{LOQ}=10 \times(\mathrm{s} / \mathrm{S})$

where $s$ is the standard deviation of the lower level of detection (7 injections) and $\mathrm{S}$ is the slope of the curve. 
Table 2. Retention times and calibration curves of the pesticides in water

\begin{tabular}{lclc}
\hline Pesticide & Retention time / min & Curve & $\mathrm{R}$ \\
\hline Molinate & 6.9 & $\mathrm{y}=2055331.3 \mathrm{x}-91606.9$ & 0.9949 \\
Methyl parathion & 11.9 & $\mathrm{y}=45023892.6 \mathrm{x}-3525506.1$ & 0.9937 \\
Fenitrothion & 12.7 & $\mathrm{y}=45919859.5 \mathrm{x}-3359386.9$ & 0.9963 \\
Malathion & 13.0 & $\mathrm{y}=36381803.7 \mathrm{x}-1460032.9$ & 0.9981 \\
Chlorpyrifos & 13.4 & $\mathrm{y}=44159628.2 \mathrm{x}-1695684.8$ & 0.9987 \\
Pendimethalin & 14.3 & $\mathrm{y}=1497785.7 \mathrm{x}-79709.3$ & 0.9952 \\
Triazophos & 17.6 & $\mathrm{y}=7219995.8 \mathrm{x}-1091115.5$ & 0.9903 \\
\hline
\end{tabular}

\section{Chromatographic conditions}

The analyses of the pesticides were performed using a gas chromatograph (GC-Trace, Thermo Finnigan) equipped with a split/splitless injector and a selective nitrogen-phosphorus detector (NPD). All separations were accomplished on a OV-5 column $(30 \mathrm{~m} \times 0.25 \mathrm{~mm}$ I.D. $\times 0.25 \mu \mathrm{m}$ thickness). The initial temperature of the oven was $100{ }^{\circ} \mathrm{C}$ and the temperature was increased to $150{ }^{\circ} \mathrm{C}$ at a rate of $25^{\circ} \mathrm{C} \mathrm{min}^{-1}$, then to $290{ }^{\circ} \mathrm{C}$ at a rate of $30{ }^{\circ} \mathrm{C} \mathrm{min}{ }^{-1}$. The temperatures of the injector and the detector were set at $250{ }^{\circ} \mathrm{C}$ and $300{ }^{\circ} \mathrm{C}$, respectively. The splitless injection mode was used (at $2 \mathrm{~min}$ ) and $2 \mu \mathrm{L}$ of the sample volume was injected. Helium was used as the

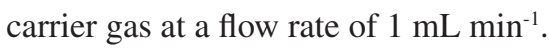

\section{Results and Discussion}

\section{Chromatographic separation and calibration curves}

Initially, solutions of individual pesticides were studied in order to determine the retention time in GC system, afterwards the mixture of the pesticides was separated using a suitable temperature program. The retention times and the calibration curves are given in Table 2. The calibration curves for all five analytes were linear over the range 0.005-1.500 $\mathrm{m} \mathrm{L}^{-1}$, as shown in Table 2. The coefficient of correlation, $\mathrm{R}$, exceeded 0.99 for all the compounds studied.

\section{Solid-phase extraction (SPE)}

\section{Selection of adsorbent and eluent}

Experiments were conducted to evaluate the recovery of the pesticides using $\mathrm{C} 18$ and florisil cartridges. The best results were obtained for $\mathrm{C} 18$ cartridges with recoveries between $75 \%$ and $107 \%$, while low recoveries were observed using florisil cartridges. Ethyl acetate (ACET) and dichloromethane (DCM) were suitable eluents on the C18 cartridges (Table 3). Ethyl acetate was selected in view of the superior recoveries (85-107\%) with respect to dichloromethane (75-106\%).

Table 3. Selection of eluent using C18 cartridges of $500 \mathrm{mg}$ per $6 \mathrm{~mL}$

\begin{tabular}{lcc}
\hline Pesticide & Ethyl acetate & Dichloromethane \\
\hline Molinate & $107.8 \pm 1.0$ & $106.8 \pm 8.7$ \\
Methyl parathion & $106.9 \pm 1.0$ & $93.0 \pm 0.1$ \\
Fenitrothion & $100.0 \pm 3.0$ & $83.3 \pm 3.5$ \\
Malathion & $102.4 \pm 9.4$ & $105.6 \pm 6.6$ \\
Chlorpyrifos & $99.9 \pm 8.0$ & $93.7 \pm 4.9$ \\
Pendimethalin & $96.9 \pm 5.9$ & $91.2 \pm 9.1$ \\
Triazophos & $85.9 \pm 6.8$ & $75.5 \pm 5.6$ \\
\hline
\end{tabular}

\section{Accuracy, precision and linearity}

The recoveries obtained for each concentration (Table 4) proved to be reproducible, as represented by the low values of the standard deviations. Neto and Siqueira, ${ }^{9}$ also used C18 cartridges and ethyl acetate as eluent to monitor organophosporus pesticides.

\section{Solid-phase microextraction (SPME)}

Effect of film thickness and nature fiber on the extraction of pesticides

Figure 1 shows the results of the extraction of pesticides by using two different SPME fibers. Clearly, the $100 \mu \mathrm{m}$ PDMS fiber shows a higher efficiency than the $75 \mu \mathrm{m}$ carboxen-PDMS. Besides the type of the fiber, the thickness may also influence the extraction efficiency, because thicker fibers tend to retain higher amounts of analytes. $^{11}$

PDMS fiber values mass calculated for parathion, malathion, chlorpyrifos, pendimethalin and triazophos were higher than carboxen-PDMS fiber, except for molinate. Thereby the values mass on PDMS fiber for chlorpyrifos and pendimethalin are particularly noteworthy because it is around 5 times higher than the 
Table 4. Results of percentages of recovery of the pesticides in water sample using SPE

\begin{tabular}{|c|c|c|c|c|}
\hline \multirow[t]{2}{*}{ Pesticide } & \multicolumn{4}{|c|}{ Percentage of recovery } \\
\hline & $1.0 \mu \mathrm{g} \mathrm{L}^{-1}$ & $2.0 \mu \mathrm{g} \mathrm{L}^{-1}$ & $4.0 \mu \mathrm{g} \mathrm{L}^{-1}$ & $8.0 \mu \mathrm{g} \mathrm{L}^{-1}$ \\
\hline Molinate & $102.3 \pm 6.2$ & $109.5 \pm 3.1$ & $107.8 \pm 1.0$ & $89.6 \pm 1.0$ \\
\hline Parathion Methyl & $110.9 \pm 2.4$ & $108.9 \pm 2.8$ & $106.9 \pm 1.0$ & $92.1 \pm 6.9$ \\
\hline Fenitrothion & $110.2 \pm 2.7$ & $109.4 \pm 5.6$ & $100.0 \pm 3.0$ & $83.0 \pm 3.4$ \\
\hline Malathion & $110.4 \pm 6.5$ & $101.9 \pm 6.7$ & $102.4 \pm 9.4$ & $105.3 \pm 4.3$ \\
\hline Chlorpyrifos & $108.2 \pm 9.5$ & $102.1 \pm 9.2$ & $99.9 \pm 8.0$ & $86.8 \pm 1.6$ \\
\hline Pendimethalin & $101.4 \pm 8.4$ & $102.3 \pm 2.4$ & $96.9 \pm 5.9$ & $78.4 \pm 5.1$ \\
\hline Triazophos & $110.7 \pm 4.4$ & $92.4 \pm 5.4$ & $85.9 \pm 6.8$ & $70.9 \pm 4.9$ \\
\hline
\end{tabular}

pesticides cited. This can be verified by the values of $\log \mathrm{K}_{\mathrm{ow}}$, shown in Table 1. The pesticides whith lower polarity, chlorpyrifos $\left(\log \mathrm{K}_{\mathrm{ow}}=4.7\right)$ and pendimentalina $\left(\log \mathrm{K}_{\mathrm{ow}}=5.2\right)$, showed a higher amount of mass retained due to higher affinity for the PDMS fiber (nonpolar). Similar results were found by Beltran et al. ${ }^{33}$ and Silva et $a l .{ }^{34}$ for extraction of organophosphorus pesticides using PDMS and PA fibers.

According to Dugay et al., ${ }^{12}$ carboxen-PDMS fibers are particularly suitable for lower-molecular-weight and more volatile analytes. Thus, the PDMS fiber of $100 \mu \mathrm{m}$ thickness was used in the subsequent studies.

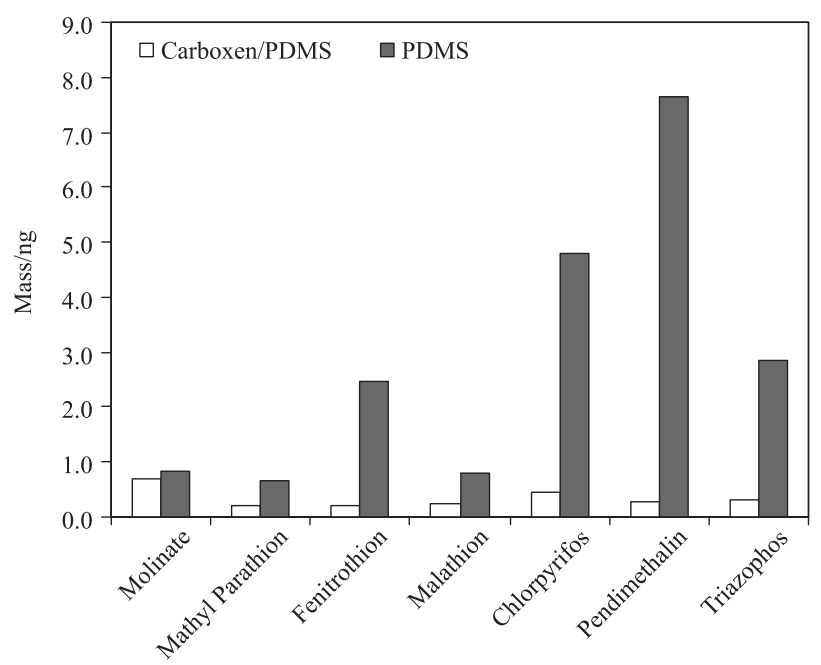

Figure 1. Extracted amount for the pesticides obtained with two different thicknesses of the polydimethylsiloxane fiber. Experimental conditions: $100 \mu \mathrm{m}$ PDMS and $75 \mu \mathrm{m}$ carboxen-PDMS fibers, 30 min extraction; sample volume, $30 \mathrm{~mL}$; stirring (150 rpm), Milli-Q water at $\mathrm{pH} 7$ and spiked with $4 \mu \mathrm{g} \mathrm{L}{ }^{-1}$ of each analyte.

\section{Experimental determination of the partition coefficient $(K)$}

It's well known that the equilibration time depends on the partition coefficient $(\mathrm{K})$ and for higher the $\mathrm{K}$ value, more the larger the amount extracted at equilibrium..$^{35}$ The results may be interpreted via the partition coefficients $(\mathrm{K})$ of the analyte between the stationary and the aqueous phase. According to equation 3, higher values of $\mathrm{K}$ give higher extraction efficiencies:

$\mathrm{K}=\frac{\mathrm{n}_{\mathrm{s}} \mathrm{V}_{\mathrm{aq}}}{\mathrm{V}_{\mathrm{s}}\left(\mathrm{V}_{\mathrm{aq}} \mathrm{C}_{\mathrm{aq}}-\mathrm{n}_{\mathrm{s}}\right)}$

where $n_{s}$ is the number of moles of analyte, $V_{a q}$ is the sample volume, $\mathrm{V}_{\mathrm{s}}$ is the volume of the stationary phase and $\mathrm{C}_{\mathrm{aq}}$ is the initial concentration of the analyte. The value of $\mathrm{V}_{\mathrm{s}}$ can be calculate as

$\mathrm{Vs}=\pi \mathrm{L}(\mathrm{e} 2+\mathrm{ea})$

where $\mathrm{e}$ is the film thickness and $\mathrm{a}$ is the diameter of the fiber of the silica rod.

Taking into account the precision on both $\mathrm{V}_{\mathrm{s}}$ and $\mathrm{n}$, and the fact that equilibrium should be reached before $n$ values can be determined, the partition coefficient values can only be approximated.

The values of $\mathrm{K}$ have been determined using two types of fibers and the values are shown in Table 5. The high values of $\mathrm{K}$ were obtained for the PDMS fiber. Although an analyte may have been more efficiently retained, the $\mathrm{K}$ values depend also the fiber thickness. The results obtained in this study show that $\mathrm{K}$ values can vary with film thickness, depending on the analyte.

Table 5. $\mathrm{K}$ values as a function of the film thickness of fibers at equilibrium

\begin{tabular}{lcc}
\hline Pesticides & $\mathrm{K}_{\mathrm{CARB} / \mathrm{PDMS}(75 \mu \mathrm{m})}$ & $\mathrm{K}_{\mathrm{PDMS}(100 \mu \mathrm{m})}$ \\
\hline Molinate & $4.03 \times 10^{2}$ & $3.15 \times 10^{2}$ \\
Methyl parathion & $1.20 \times 10^{2}$ & $2.53 \times 10^{2}$ \\
Fenitrothion & $1.15 \times 10^{2}$ & $6.16 \times 10^{2}$ \\
Malathion & $1.38 \times 10^{2}$ & $3.09 \times 10^{2}$ \\
Chlorpyrifos & $2.07 \times 10^{2}$ & $7.77 \times 10^{2}$ \\
Pendimethalin & $1.66 \times 10^{2}$ & $8.95 \times 10^{2}$ \\
Triazophos & $1.88 \times 10^{2}$ & $6.73 \times 10^{2}$ \\
\hline
\end{tabular}




\section{Determination of the equilibrium time}

The study of the equilibrium time was carried out by determining the extracted amount as a function of the exposure time obtained with the PDMS fiber at a concentration of $4.0 \mu \mathrm{g} \mathrm{L} \mathrm{L}^{-1}$. According to the results the equilibrium is reached in about 30 min for most compounds, except for chlorpyrifos and pendimethalin. Thus, we adopted a time of $45 \mathrm{~min}$ for further studies to ensure total retention of the pesticides. Other authors also found times between 15 and 45 min suitable for extraction of pesticides from water. ${ }^{16,36,37}$

Clearly, water solubility was important, but not the only, factor in determining the overall partition ratio for a given analyte between the carboxen- PDMS fiber coating and water.

\section{Variation of the sample volume}

Different volumes were investigated for the extraction of pesticides by SPME. As shown in Table 6, it appears that a volume of $40 \mathrm{~mL}$ is sufficient for recovery of the pesticides under the conditions used, and, therefore, this volume was used for subsequent experiments.

\section{Influence of $p H$ of the sample}

The Figure 2 shows the effect of $\mathrm{pH}$ of the sample in the retention of pesticides using SPME. According to the results, at pH 3, 7 and 9 did not significantly influence the extraction of pesticides molinate, atrazine, methyl parathion, fenitrothion, pendimentalina and triazophos. The pesticide malathion and chlorpyrifos were extracted with higher efficiency at $\mathrm{pH} 7$.

Table 6. Sample volume used for extraction of pesticides by SPME

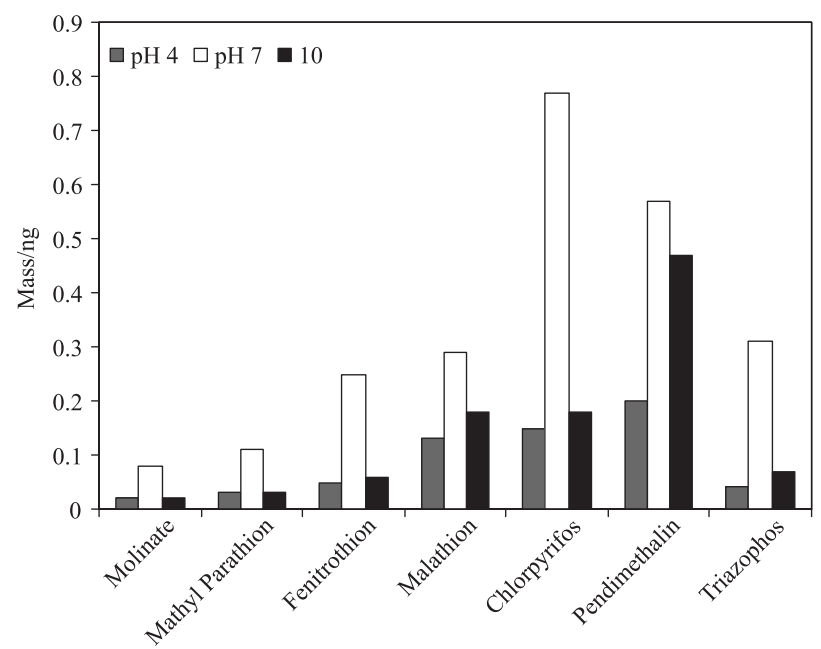

Figure 2. Influence of $\mathrm{pH}$ of the sample. Experimental conditions: $100 \mu \mathrm{m}$ PDMS, 30 min extraction; sample volume $30 \mathrm{~mL}$; stirring (150 rpm) and $1 \mu \mathrm{g} \mathrm{L}^{-1}$ of each analyte.

\section{Efficiency of extraction by SPME}

The efficiency of extraction of the pesticides was evaluated using four concentrations. The response was linear in the concentration range studied ( 1.0 to $8.0 \mu \mathrm{g} \mathrm{L}^{-1}$ ), as represented by the correlation coefficients of about 1 . The calibration curves and recoverie rates of the pesticides after extraction by SPME are show in Table 7.

\section{Comparison of SPE and SPME extraction efficiencies}

Table 8 summarizes the limits of detection (LOD) and limits of quantification (LOQ) values calculated for

\begin{tabular}{|c|c|c|c|c|c|c|c|}
\hline \multirow{2}{*}{ Volume / mL } & \multicolumn{7}{|c|}{ mass / ng } \\
\hline & Molinate & Methyl parathion & Fenitrothion & Malathion & Chlorpyrifos & Pendimethalin & Triazophos \\
\hline 20 & 0.86 & 0.61 & 1.49 & 0.78 & 3.12 & 3.94 & 1.00 \\
\hline 40 & 0.87 & 0.77 & 1.68 & 0.91 & 3.38 & 3.96 & 1.79 \\
\hline 80 & 0.73 & 0.84 & 1.78 & 1.03 & 3.54 & 3.12 & 1.46 \\
\hline
\end{tabular}

Table 7. Calibration curves and percentage of recovery of the pesticides after extraction by SPME

\begin{tabular}{|c|c|c|c|c|c|c|}
\hline \multirow[t]{2}{*}{ Pesticide } & \multicolumn{4}{|c|}{ Percentage of recovery } & \multirow{2}{*}{ Curve } & \multirow{2}{*}{$\mathrm{R}$} \\
\hline & $1.0 \mu \mathrm{g} \mathrm{L}-1$ & $2.0 \mu \mathrm{g} \mathrm{L}-1$ & $4.0 \mu \mathrm{g} \mathrm{L}-1$ & $8.0 \mu \mathrm{g} \mathrm{L}^{-1}$ & & \\
\hline Molinate & $94.1 \pm 5.2$ & $97.5 \pm 7.8$ & $104.4 \pm 8.3$ & $99.1 \pm 5.3$ & $y=151049182.6 x+157838.5$ & 0.9985 \\
\hline Methyl parathion & $102.8 \pm 9.8$ & $96.2 \pm 6.2$ & $101.6 \pm 3.7$ & $99.8 \pm 6.8$ & $y=2893135373.9 x+683244.3$ & 0.9996 \\
\hline Fenitrothion & $99.1 \pm 6.3$ & $95.2 \pm 7.1$ & $94.3 \pm 4.6$ & $101.4 \pm 4.2$ & $y=9057371182.6 x-1214367.4$ & 0.9959 \\
\hline Malathion & $74.8 \pm 9.1$ & $102.6 \pm 8.4$ & $109.1 \pm 8.4$ & $98.0 \pm 5.6$ & $y=2803993600.0 x+2588769.0$ & 0.9923 \\
\hline Chlorpyrifos & $108.6 \pm 4.2$ & $87.3 \pm 5.9$ & $101.0 \pm 6.8$ & $100.2 \pm 8.3$ & $y=9226153156.5 x+7819595.9$ & 0.9964 \\
\hline Pendimethalin & $105.0 \pm 8.7$ & $93.2 \pm 7.3$ & $91.7 \pm 4.5$ & $102.0 \pm 7.4$ & $y=389266365.2 x+134198.1$ & 0.9914 \\
\hline Triazophos & $103.0 \pm 5.4$ & $87.6 \pm 6.5$ & $101.8 \pm 4.0$ & $100.1 \pm 9.5$ & $y=1482497147.8 x-301649.3$ & 0.9967 \\
\hline
\end{tabular}


Table 8. Limits of detection (LOD) and limits of quantification (LOQ) of pesticides analized whith SPE and SPME, and the maximum limit permitted in Brazil

\begin{tabular}{|c|c|c|c|c|c|c|c|}
\hline \multirow[t]{2}{*}{ Pesticide } & \multicolumn{2}{|c|}{ SPE } & \multicolumn{2}{|c|}{ SPME } & \multicolumn{3}{|c|}{ Maximum limit permitted / $\left(\mu \mathrm{g} \mathrm{L}^{-1}\right)$} \\
\hline & $\begin{array}{l}\mathrm{LOD} / \\
\left(\mu \mathrm{g} \mathrm{L}^{-1}\right)\end{array}$ & $\begin{array}{l}\mathrm{LOQ} / \\
\left(\mu \mathrm{g} \mathrm{L}^{-1}\right)\end{array}$ & $\begin{array}{l}\mathrm{LOD} / \\
\left(\mu \mathrm{g} \mathrm{L}^{-1}\right)\end{array}$ & $\begin{array}{l}\mathrm{LOQ} / \\
\left(\mu \mathrm{g} \mathrm{L}^{-1}\right)\end{array}$ & $\begin{array}{c}\text { Portaria MS } \\
518 / 2004\end{array}$ & $\begin{array}{c}\text { Conama } \\
357 / 2005\end{array}$ & $\begin{array}{r}\text { Conama } \\
396 / 2008\end{array}$ \\
\hline Molinate & 0.23 & 0.70 & 0.36 & 1.08 & 6 & - & 6 \\
\hline Methyl parathion & 0.09 & 0.27 & 0.02 & 0.07 & - & - & - \\
\hline Fenitrothion & 0.12 & 0.36 & 0.01 & 0.03 & - & - & - \\
\hline Malathion & 0.21 & 0.63 & 0.07 & 0.22 & - & 100 & 190 \\
\hline Chlorpyrifos & 0.37 & 1.14 & 0.03 & 0.09 & - & - & 30 \\
\hline Pendimethalin & 0.36 & 1.08 & 0.08 & 0.23 & 20 & - & 20 \\
\hline Triazophos & 0.23 & 0.69 & 0.08 & 0.25 & - & - & - \\
\hline
\end{tabular}

Table 9. Limits of detection (LOD) of the pesticides using different analytical techniques and comparison with our results

\begin{tabular}{lccc}
\hline Pesticide & \multicolumn{2}{c}{${\text { LOD / }\left(\mu \mathrm{g} \mathrm{L}{ }^{-1}\right)}$} \\
\cline { 2 - 4 } & PDMS/GC-NPD (present study) & PA / GC-MS & \\
\hline Molinate & 0.356 & PDMS / GC-NPD $^{38}$ & CW-DVB / GC-NPD $^{12}$ \\
Methyl parathion & 0.023 & 0.136 & \\
Fenitrothion & 0.010 & 0.008 & 0.03 \\
Malathion & 0.072 & & 0.04 \\
Chlorpyrifos & 0.030 & & 0.03 \\
Fenamiphos & & & 0.05 \\
Pendimethalin & 0.076 & & 0.02 \\
Triazophos & 0.083 & 0.056 & \\
\hline
\end{tabular}

all analytes studied, beyond maximum limit permitted in the Brazil. The LOD values using SPME for parathion, malathion, fenitrothion, chlorpyrifos, pendimethalin and triazophos were lower than LOD using SPE, except for molinate. Thereby the LOD value using SPME for malathion is particularly noteworthy because it is around 50 times lower than the regulatory limit cited in CONAMA (Brazil). Tomkins and Ilgner, ${ }^{38}$ found similar results for malathion using a 65 -mm thickness polydimethylsiloxanedivinylbenzene (PDMS-DVB) fiber.

Table 9 gives the detection limit of some pesticides found by other authors ${ }^{33,39}$ by using different SPME fibers with detection by GC-NPD or GC-MS system. The values are comparable to those found in the present study.

The extraction efficiencies for SPME and SPE are comparable and concentration levels below those required in current legislation were attained (Table 8). For routine analysis, SPME should be preferred because of the rapidity, sensibility, and free-solvent.

\section{Conclusions}

The present study shows that both solid-phase extraction (SPE) and solid-phase microextraction (SPME) are highly efficient for the analysis of pesticides using $\mathrm{C} 18$ cartridges and ethyl acetate as the eluent, as represented by the high recovery rates. The best conditions for SPME were obtained with a PDMS fiber of $100 \mu \mathrm{m}$ thickness, a sample volume of $40 \mathrm{~mL}$, and an equilibration time of $45 \mathrm{~min}$. Both procedures showed a linear response in the concentration range between 1.0 and $8.0 \mu \mathrm{g} \mathrm{L}^{-1}$. SPME is most suitable for the analysis of pesticides in water based on the rapidity of the method and the restricted use of eluent. The limits of detection and the limits of quantification are well below the maximum limits set by the Brazilian authorities.

\section{Acknowledgments}

The authors are grateful to the support from CNPq, CAPES, FUNCAP and Fundação Nucleo de Tecnologia Industrial do Ceará - NUTEC (Proc. No. 223.02.00/09).

\section{References}

1. http://www.visaobrasil.org/2010/03/ accessed in March 2011.

2. http://www.mmcbrasil.com.br/ accessed in April 2010.

3. Spiro, T. G.; Stigliani,W. M.; Química Ambiental; Pearson: São Paulo, Brasil, 2008. 
4. http://portal.saude.gov.br/portal/arquivos/pdf/portaria_518.pdf accessed in May 2011.

5. http://www.mma.gov.br/port/conama/res/res05/res35705.pdf accessed in May 2011.

6. http://www.mma.gov.br/port/conama/legiabre. cfm?codlegi=562 accessed in May 2011.

7. Brito, N. M.; Junior, O. P. A.; Polese, L.; Pesticidas: R. Ecotoxicol. Meio Ambiente 2003, 13, 129.

8. Rissato, S. R.; Libânio, M.; Giafferis, G. P.; Gerenutti, M.; Quim. Nova 2004, 27, 739.

9. Neto, A. J. S.; Siqueira, M. E. P. B.; Quim. Nova 2005, $28,747$.

10. Eaton, A. D.; Clesceri, L. S.; Rice, E. W.; Greenberg, A. E.; Standard Methods for the Examination of Water and Wastewater, 21 ${ }^{\text {th }}$ ed.; American Public Health Association: Washington, 2005, ch. 6.

11. Pawliszyn, J.; Solid Phase Microextraction - Theory and Practice, Wiley-VCH: Canada, 1997.

12. Dugay, J.; Miege, C.; Hennion, M.-C.; J. Chromatogr., A 1998, 795, 27.

13. Fytianos, K.; Raikos, N.; Theodoridis, G.; Velinova, Z.; Tsoukali, H.; Chemosphere 2006, 65, 2090.

14. Blasco, C.; Fernández, M.; Pico, Y.; Font, G.; J. Chromatogr., A 2004, 1030, 77.

15. Chagas, C. M.; Queiroz, M. E. L. R.; Neves, A. A.; Queiroz, J. H.; Oliveira, T. T.; Nagem, T. J.; Quim. Nova 1999, 22, 506.

16. Sauret-Szczepanski, N.; Mirabel, P.; Wortham, H.; Environ. Pollut. 2006, 139, 133.

17. Simões, N. G.; Cardoso, V. V.; Ferreira, E.; Benoliel, M. J.; Almeida, C. M. M.; Chemosphere 2007, 68, 501.

18. Tomkins, B. A.; Ilgner, R. H.; J. Chromatogr., A 2002, 972, 183.

19. Filho, A. M.; dos Santos, F. N.; Pereira, P. A. P.; Microchem. J. 2010, 96, 139.

20. Sng, M. T.; Lee, F. K.; Lakso, H. A.; J. Chromatogr., A 1997, 759, 225.

21. Boussahel, S.; Bouland, K. M.; Moussaoui, M.; Baudu, A.; Water Res. 2002, 36, 1909.
22. Sakamoto, M.; Tsutsumi, T.; J. Chromatogr., A 2004, 1028, 63.

23. Dong, C.; Zeng, Z.; Yang, M.; Water Res. 2005, 39, 4204.

24. Passeport, E.; Guenne, A.; Culhaoglu, T.; Moreau, S.; Bouyé, J.-M.; Tournebize, J.; J. Chromatogr., A 2010, 1217, 5317.

25. Pinto, M. I.; Sontag, G.; Bernardino, R. J.; Noronha, J. P.; Microchem. J. 2010, 96, 225.

26. Tankiewicz, M.; Fenik, J.; Biziuk, M.; TrAC, Trends Anal. Chem. 2000, 29, 1050.

27. Krutz, J.; Senseman L. S.A.; Sciumbato, A. S.; J. Chromatogr., A 2003, 999, 103.

28. Quintana, J.; Martí, I.; Ventura, F.; J. Chromatogr., A 2001, 938, 3.

29. Natangelo, M.; Tavazzi, S.; Fanelli, R.; Benfenati, E.; J. Chromatogr., A 1999, 859, 193.

30. Nogueira, J. M. F.; Sandra, T.; Sandra, P.; Anal. Chim. Acta 2004, 505, 209.

31. Gervais, G.; Brosillon, S.; Laplanche, A.; Helen C.; J. Chromatogr., A 2008, 1202, 163.

32. Milhome, M. A. L.; Sousa, D. O. B.; Lima, F. A. F.; Nascimento, R. F.; Eng. Sanit. Ambient. 2009, 14, 363.

33. Beltran, J.; Lopez, F. J.; Cepria, O.; Hernandez, F.; J. Chromatogr., A 1998, 808, 257.

34. Silva, F. C.; Cardel, Z. L.; Carvalho, C. R.; Quim. Nova 1999, $22,197$.

35. Zimmermann, T.; Ensinger, W. J.; Schmidt, T. C.; J. Chromatogr., A 2006, 1102, 51.

36. Barrionuevo W. R.; Lanças, F. M.; Quim. Nova 2001, 24, 172.

37. Komatsu, E.; Vaz, J. M.; Quim. Nova 2004, 27, 720.

38. Tomkins, B. A.; Ilgner, R. H.; J. Chromatogr., A 2002, 972, 183.

39. Valor, I.; Moltó, J. C.; Apraiz, D.; Font, G.; J. Chromatogr., A 1997, 767, 195. 